\title{
Design, construction, operation and the effect of fines content and permeability on the seismic performance of tailings sand dams in Chile
}

\author{
Diseño, construcción, operación y el efecto del contenido de finos y la permeabilidad en el \\ desempeño sísmico de presas de relave de arena en Chile \\ Fecha de entrega: 15 de diciembre 2015 \\ Fecha de aceptación: 2 de junio 2016
}

\section{Luis Valenzuela}

Geotechnical consultant, Montecassino 929, las Condes, Santiago, Chile (formerly Arcadis Chile), valenzuelapluis@gmail.cl

The significant growth of the metallic mining industry over the last few decades has made the construction of tailings deposits of large dimensions necessary, tailings being the fine mining waste resulting from the milling and concentration processes. The most common types of tailings dam in mining are the tailings sand dam, a special kind of hydraulic fill dam, for two main reasons: because such dams need to be built over a long period of time, and due to the low cost of sand available from the tailings. In particular, this paper analyses the behaviour of tailings dams in Chile, one of the most seismically active countries in the world. The design and construction of tailings dams, as well as the effect of drain gravels and filter materials on the geotechnical behaviour of the tailings sands, are also discussed. The importance of the operational phase is addressed, because in tailings dams this phase can last many years and be the determinant in the final behaviour of the dams. Finally, recommendations to mitigate risks along the complete life cycle of the dams are given, and permeability and fines content effects as well as sand tailings drained and undrained strength are considered.

Keywords: tailings dams, sand dams, dam failures, mining
El crecimiento significativo de la industría minera metálica en las recientes últimas decádas, ha hecho necesaria la construcción de depósitos de relave de grandes dimensiones. Los relaves son el desecho fino que resulta de los procesos de molienda y concentrado. Por dos razones principalmente, el tipo más común de presa de relaves en minería es la presa de arena de relaves, un tipo especial de presa de relleno hidráulico. Esto porque este tipo de presas se deben construir durante un periodo largo de tiempo y debido al bajo costo de la arena disponible de los relaves. Este artículo analiza el comportamiento de presas de relave en Chile, uno de los países más activos sísmicamente en el mundo. Se discute el diseño y construcción de presas de relaves, así como también el efecto de drenes de gravas y materiales de filtro en el comportamiento geotécnico de arenas de relaves. Se enfatiza la importancia de la fase operacional porque esta fase puede durar muchos años y ser determinante en el comportamiento final de las presas de relaves. Finalmente, se dan recomendaciones para mitigar los riesgos a lo largo del ciclo de vida completa de las presas y se considera también el efecto de la permeabilidad y contenido de finos además de la resistencia drenada y no drenada de las arenas de relaves.

Palabras clave: presas de relaves, presas de tierra, fallas de presas, minería

fill dams that use waste rock from the mine when available at an economical transport distance. In contrast with hydraulic fill dams for water reservoirs, the material used to build tailings sand dams is not natural borrowed soil, but the mine tailings themselves. A centrifugal mechanical device called a cyclone separates the tailings into a coarse portion, generically referred to as sand, and a fine portion, generally referred to as slime (Figure 1a). Figure 1b shows a typical particle size distribution range for copper tailings (feed) and for the resulting sands (underflow) and slimes 
a)

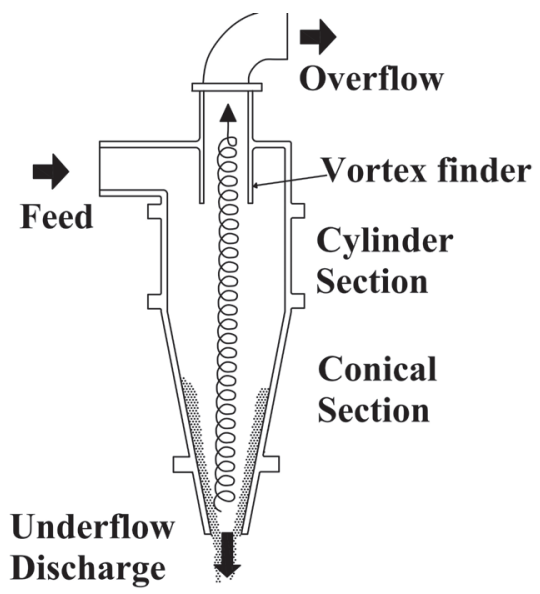

b)

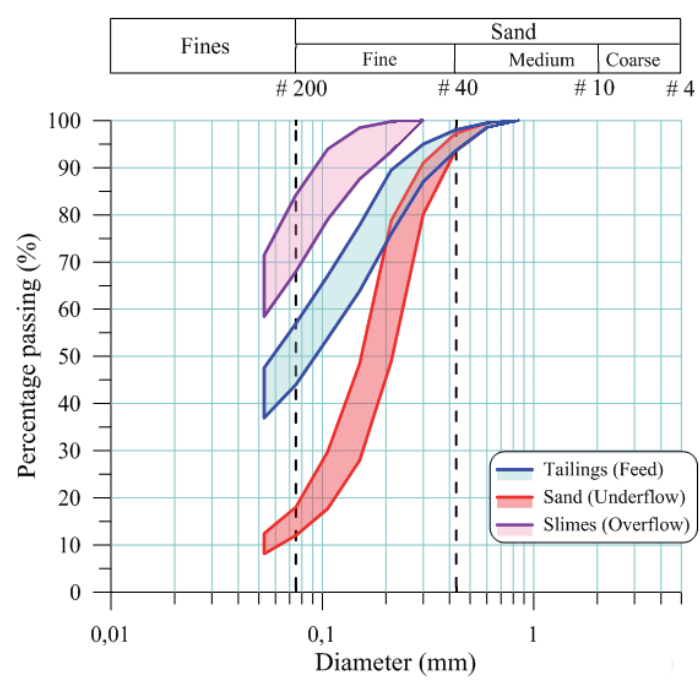

Figure 1: a) Scheme of a cyclone and b) typical range of particle size distribution for tailings (feed), sands (underflow), and slimes (overflow).

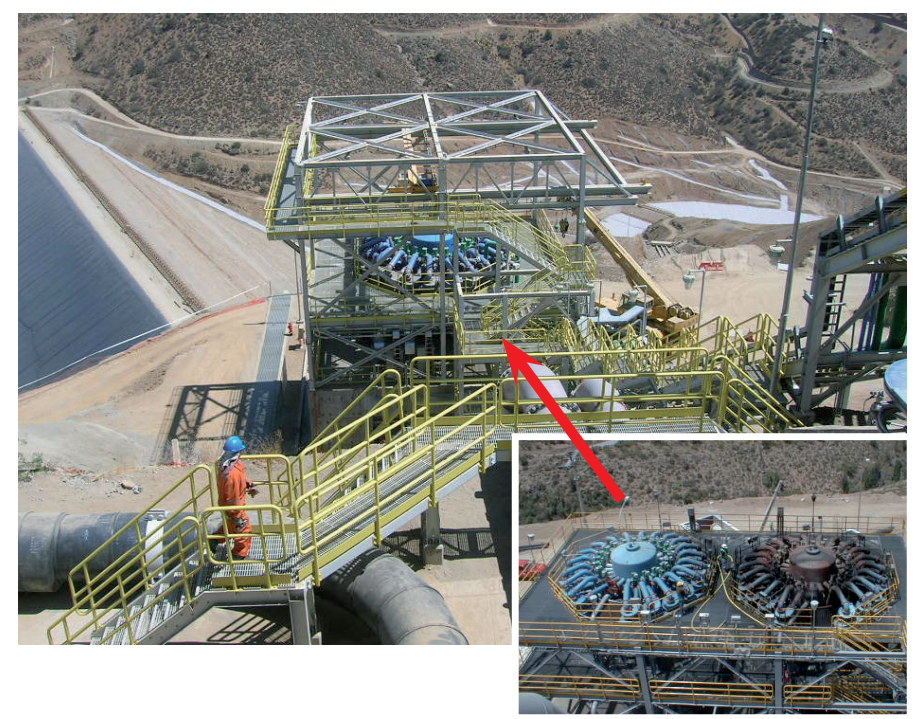

Figure 2: Cluster of cyclones from Quillayes tailings deposit (overflow) after the cycloning process. The sand portion is used to build up the dam via hydraulic deposition.

Cyclones may operate individually or in a cluster consisting of several cyclones (Figure 2). Both types of cyclone may be fixed or mobile, the latter being able to move on the crest of the dam under construction.

There are three basic types of tailings dam constructed via hydraulic deposition of sand, referred to as upstream, centerline and downstream, according to their method of growth, as indicated in Figure 3.

In the construction of these dams, sand can be deposited hydraulically directly on the growing dam slope or, alternatively, deposited in cells as shown on Figure 4. Both deposition methods allow for sand to be compacted in layers thin enough to attain design densities, especially in the downstream and centerline construction methods.

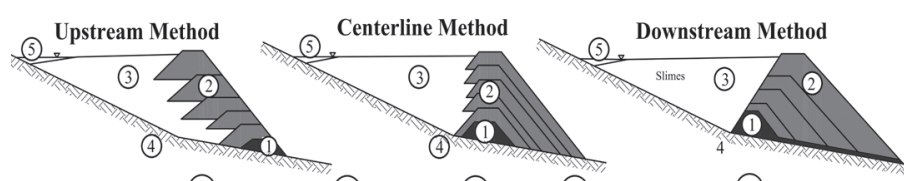

(1) Starter dam" (2) Sand dam (3) Slimes (4) Foundation Soil (5) Pond

Figure 3: Typical cross sections of tailings dams based on their growth method.
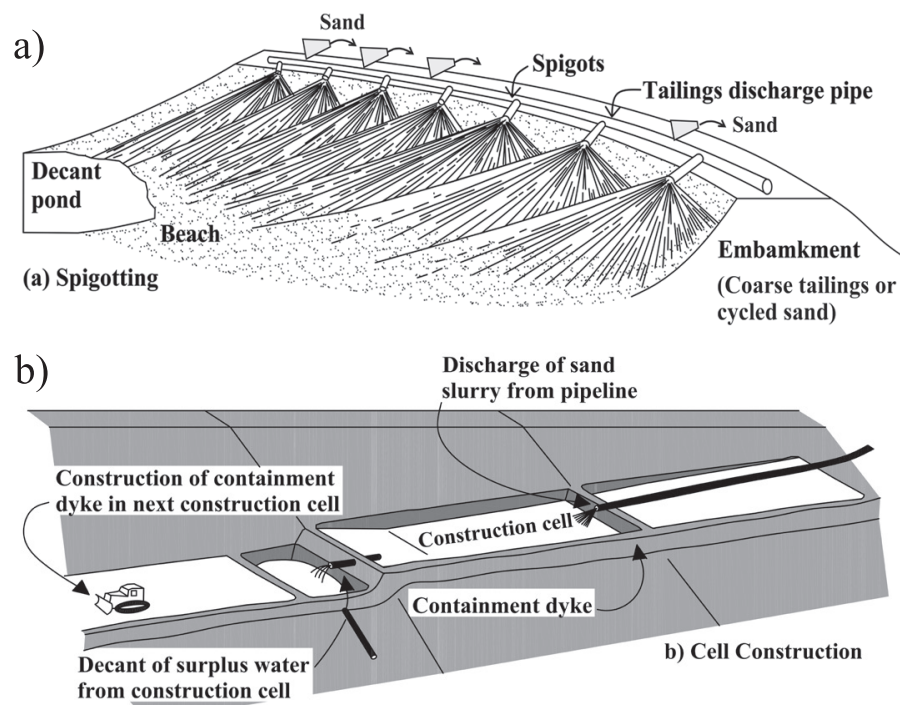

Figure 4: a) Sand deposited on the slope from the dam crest and b) sand deposited in cells

Examples of the various possible arrangements, as well as of other types of tailings dams and construction methods that have been used in various mining regions worldwide have been discussed in several publications, such as Vick (1983) and Blight (2010). The present paper deals only 
with the case of tailings sand dams that close a gully or a valley in a narrow sector. This is a common condition in large-scale mines in the American continent, which in many cases are located in mountain ranges, frequently resulting in the construction of tall dams.

\section{General performance of tailings sand dams}

Tailings sand dams are perceived to be relatively vulnerable structures that do not provide the same safety as conventional dams built for water impoundments or for power generation. This perception is, of course, related to the fact that the stability of sand dams depends on the geotechnical behaviour of hydraulically deposited sands subjected to a limited compacting effort, and therefore, supposedly susceptible to liquefaction. The regrettable history of tailings dam failures, several of them including fatalities and/or extensive contamination downstream from the dam, has prompted negative community perception. Figure 5 shows statistics of failure of conventional dams and tailings dams reported between 1800 and 2000, according to $\operatorname{ICOLD}(1995,2001)$.

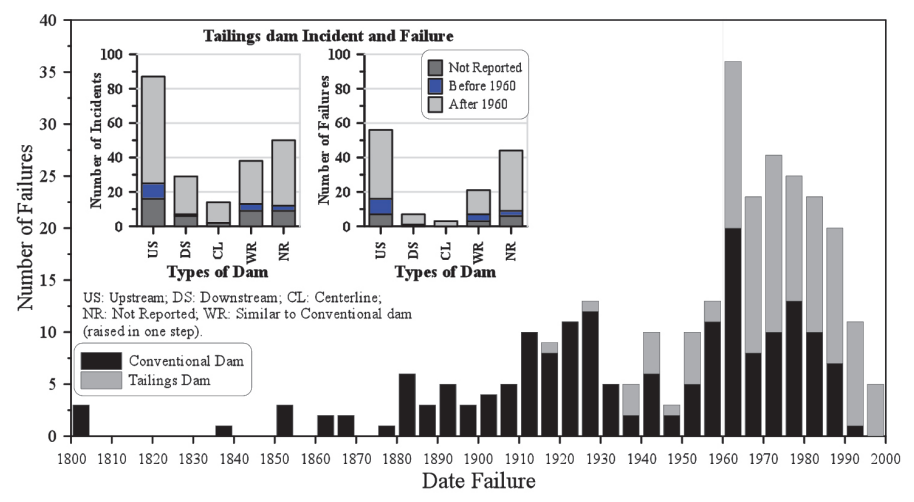

Figure 5: Statistics on dam failures according to ICOLD (1995, 2001)

Figure 5 shows that, during the period between years 1800 and 2000, the recorded number of tailings dam failures represents $40 \%$ of the total number of failures. However, this percentage increased considerably between 1960 and 2000 , reaching $70 \%$. This increase occurred in the period when the mining industry, especially metal mining, experienced a major production increase. The probability of failure of tailings dams has been estimated to be of the order of 1:700 to 1:1750 (Davies et al., 2000), a figure that is much higher than for conventional dams used for water impoundment, estimated some years ago by Peck (1980) at 1:10000. Figures obtained in recent years have indicated from two to five failures annually, a situation that merits concern. Three major dams failed in different world locations in 2014 alone (Priscu, 2014), the failure of the Mount Polley dam outstanding among them. Even though there were no fatalities in this failure, it attracted the attention of specialists and official agencies around the world, in part because it occurred in British Columbia, Canada, where regulations as well as design and operational practices had been considered exemplary. In 2015 the failure of Fundao upstream tailings dam in Brazil, still under investigation, caused 20 fatalities, the destruction of the town of Bento Rodrigues located $2 \mathrm{~km}$ downstream of the dam and the contamination of downstream river for several kilometers.

Published statistics have shown that tailings dams constructed using the upstream method have frequently suffered some type of incident ${ }^{1}$, as shown in Figure 5. Historically, upstream dams have been the most common and numerous tailings dams, as they are more economical in both investment and operating cost. The number of sand dams constructed by other methods - downstream and centerline - and even using other materials, such as rockfill or compacted earth, has grown significantly during the last three to four decades, but in relative terms upstream dams continue to fail most often, especially in highly seismic countries such as Chile and Japan. In China, Wei et al. (2013) mention that the majority of tailings dam failures have been upstream dams, which caused 573 fatalities between 1962 and 2008. However, the authors acknowledge the numerous upstream dams in China that have performed satisfactorily, as discussed below.

Aside from construction method, there are general characteristics of tailings dams that make them relatively more vulnerable than other dams to certain situations, unless special care is taken in their design, construction, and operation. These characteristics are mainly the liquefaction potential of saturated and close-to-saturation sands, and their low erosion resistance. Although the figures mentioned by ICOLD (2001) are not explicit and do not contain complete details in all cases - for instance

\footnotetext{
${ }^{1}$ Incidents include three categories, according to USCOLD (1994) 0: failures, accidents, and groundwater. Failure is defined as breach of an embankment leading to release of impounded tailings; accident is defined as physical damage to the embankment that does not result in release of impounded tailings; groundwater is defined as the failure of an engineered design feature to control groundwater contamination in the manner intended.
} 
the precise causes of the dam failures or accidents, or sometimes even the type of dam - certain major conclusions can be drawn from them. Considering the number of failures - excluding accidents and shortcomings in control of contamination through seepage - and their relationship to the type of dam, it is clear that far more failures involved upstream dams (56) than downstream (7) and centerline dams (3). It should be mentioned however, that prior to the 1960s, most tailings dams were of the upstream type, which would indicate bias in the statistics. On the other hand, although downstream and centerline tailings dams constructed since then have been significantly higher than in past decades, their performance has been markedly better.

In fact, although Chile is essentially a mining country with a mountainous topography in one of the most seismically active regions in the world, there have been no recorded failures of downstream or centerline dams, except for some minor incidents with minimal damage, whereas several failures have occurred in upstream dams, with at least two catastrophic cases. Industry, regulatory agencies, and specialists agree that downstream and centerline tailings sand dams - adequately designed, constructed, and operated - are intrinsically safer than upstream dams. The stability of the downstream dam is independent of the geotechnical and dynamic characteristics of the tailings and slimes retained by the dam. The geometry of these dams facilitates hydraulic deposition and compaction of sands, and also reduces the saturated zone in the dam body to a minimum. These characteristics prevent the risk of liquefaction and flow failure, from either an increase in static stress such as excessive deformation of foundation strata, or dynamic stresses from a seismic event. However, independently of the stability conditions that favour downstream and centerline dams, there are other causes of dam failure, for instance if no adequate water management measures are applied or if design and design criteria are not respected at any point during the construction and operation of the deposit. These aspects will be discussed later in this paper.

\section{Failure of upstream tailings sand dams in major earthquakes}

We include below a description of some tailings dam failures in Chile, each of them associated with a major earthquake in the general region where these dams are located:

\section{Barahona $N^{\circ} 1$ dam (1928)}

Failure of this tailings dam, located in the Andes mountain range at an elevation of 1650 masl at El Teniente mine 80 $\mathrm{km}$ south-east of the city of Santiago in Chile's central zone, has been described by Agüero (1929), Troncoso et al. (1993) and Troncoso (2014). This failure occurred as a consequence of the 1928 Talca earthquake, magnitude $M_{\mathrm{s}}=8.3$, with its epicenter $180 \mathrm{~km}$ from the dam. The failure caused the release of some $2.7 \mathrm{Mm}^{3}$ (Millions of $\mathrm{m}^{3}$ ) of tailings, which descended through the canyon of the Cachapoal River, causing the death of 54 persons. This was a $65 \mathrm{~m}$ high upstream dam that was not compacted. Failure of the dam was due to liquefaction and flow of tailings. In this dam, as in other similar ones, low undrained resistance of slimes contributed to the failure. Figure 6a shows a cross-section of the dam and failure surface which had a downstream slope of 1:2 (V: H), according to Troncoso et al. (1993). This dam was reconstructed later and, although not in operation today, has been the object of recent reinforcements, completed in 2009. The dam now serves as an emergency deposit (Troncoso, 2015). The reinforced dam did not suffer damage during the Maule earthquake in February $2010\left(M_{\mathrm{w}}=8.8\right)$, although it is located only $133 \mathrm{~km}$ from the plate rupture zone associated with the earthquake.

a)

Elevation 1602
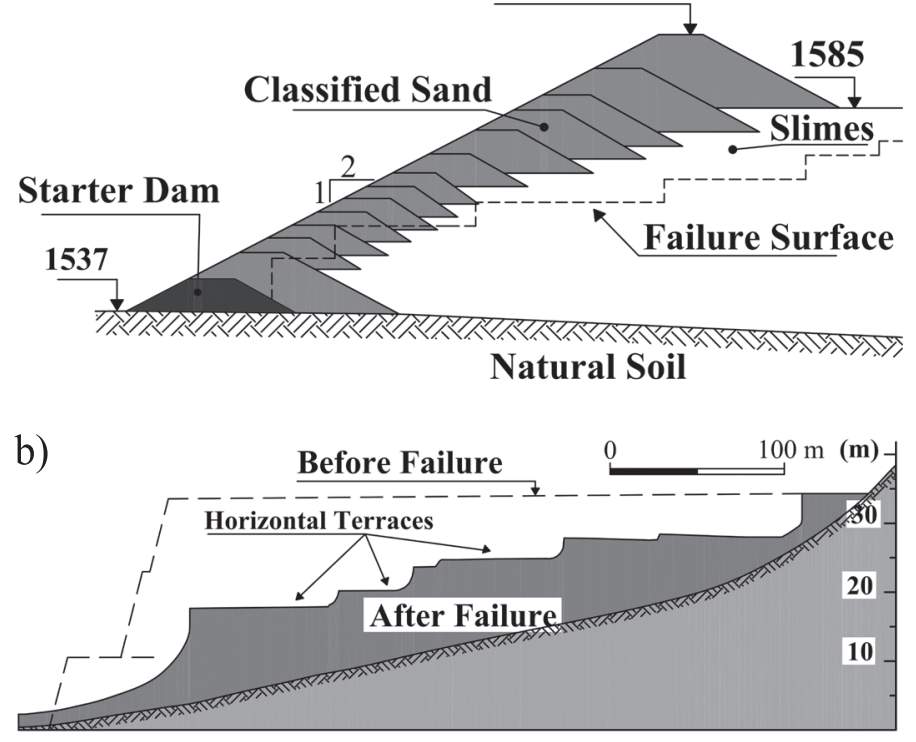

Figure 6: a) Cross-section of the Barahona $\mathrm{N}^{\circ} .1$ dam, showing the failure mechanism (Troncoso et al., 1993) and b) El Cobre $\mathrm{N}^{\circ} 1$ dam profile before and after the failure (Dobry and Alvarez, 1967) 


\section{El Cobre $N^{\circ} 1$ dam (1965)}

This is the failure that is best known internationally, given its disastrous consequences: more than 200 people dead, and widespread contamination of an agricultural valley. The failure occurred during the $1965 M_{\mathrm{s}}=7.4$ earthquake in central Chile, the epicenter of which was only $40 \mathrm{~km}$ away from the dam. The details have been described by Dobry and Alvarez (1967). This was an upstream dam, and its failure was due to liquefaction of sands and tailings flows (Figure 6b). El Cobre $\mathrm{N}^{\circ} 1$ was located downstream of El Cobre dams $\mathrm{N}^{\circ} 2$ and $\mathrm{N}^{\circ} 3$. All three were upstream dams, although El Cobre $\mathrm{N}^{\circ}$, located upstream of the other two, was at one time modified to operate briefly in a combination of downstream/centerline growth.

\section{Cerro Negro dam (1985)}

Cerro Negro is an upstream and centerline growth dam of $30 \mathrm{~m}$ high. As a consequence of the Valparaíso earthquake in 1985, of $M_{\mathrm{s}}=7.8$ magnitude, a portion of the central part of the dam failed, releasing close to 130000 tons of tailings and tailings sands, which flowed $8 \mathrm{~km}$ downstream. The failure was caused by cracks in the dam, liquefaction of slimes and tailings, overtopping of the dam, and flow of tailings, and has been described by Castro and Troncoso (1989).

\section{Tailings dams affected by the 27F 2010 earthquake}

The Maule earthquake was the sixth largest earthquake recorded worldwide ( $M_{\mathrm{w}}=8.8$ magnitude), and involved a nearly $500 \mathrm{~km}$-long rupture N-S zone between the Nazca and South American plates, approximately between the cities of Concepción and San Antonio (Ramirez, 2010; Valenzuela, 2010; Verdugo, 2011; Villavicencio et al., 2014; Troncoso, 2014). The following tailings dams failed during this earthquake:

Las Palmas, located $120 \mathrm{~km}$ from the epicenter, at Pencahue, and $90 \mathrm{~km}$ from the plate rupture zone associated with the earthquake. Las Palmas was a $15 \mathrm{~m}$ high dam that had not been in operation since 1997 and had had incomplete and inadequate closure work. It failed due to liquefaction of the base of the dam and flow of tailings, causing 4 deaths. Its mode of construction is not clear; it was apparently started as a downstream dam, but rested on the tailings during its last phase.
Veta del Agua, located approximately $390 \mathrm{~km}$ from the epicenter near the town of Nogales and $60 \mathrm{~km}$ from the plate rupture zone, was actually a set of upstream dams that had been operated deficiently. The dam that failed in 2010 was dam $\mathrm{N}^{\circ} 1$, which was around $17 \mathrm{~m}$ high. During the 1981 earthquake $\left(M_{\mathrm{s}}=6.5\right)$, the $20 \mathrm{~m}$ high Veta del Agua $\mathrm{N}^{\circ} 2$ dam failed (Villavicencio et al., 2014), and during the 1985 earthquake $\left(M_{\mathrm{s}}=7.8\right)$ the $24 \mathrm{~m}$ high Veta del Agua $\mathrm{N}^{\circ} 1$ dam failed (Castro and Troncoso, 1989).

Chancón, $270 \mathrm{~km}$ from the epicenter in the Chancón area, is about $130 \mathrm{~km}$ from the plate rupture zone. It was an old dam, no longer in operation, to which a new tailings impoundment had been added. Instability of the sand dam due to longitudinal cracks, subsidence and displacements caused a reduction in capacity of the new impoundment.

Bellavista, a $14 \mathrm{~m}$ high upstream dam, is located 390 $\mathrm{km}$ from the epicenter near El Asiento and $85 \mathrm{~km}$ from the plate rupture zone. Instability in the dam caused by longitudinal cracks, settlement, and shifting, produced collapse of approximately $80 \%$ of the sand dam.

The Chilean experience indicates that even in earthquakes of great magnitude, all failures have occurred in upstream dams, with the exception of the damage suffered by Alhué dam, a downstream dam only 8 to $13 \mathrm{~m}$ high, that suffered an accident during the earthquake, due to design problems in the drainage system and a low degree of compaction. Every one of the dams that failed was relatively minor in terms of height and impounded volume, and with the exception of Alhué, had been either improperly closed without maintenance, or was operative but with low technical requirements and poor quality control.

The experience in Japan is similar in that the majority of tailings dams that have failed have done so from earthquakes, and that among those dams, many were of upstream construction (Ishihara, 1984; Ishihara et al., 2015). Examples of the above are shown in Figure 7 and 8. ICOLD (2001) indicates that some downstream dams in Japan were also damaged in the 1978 earthquake ( $M=$ 7), but the damage was classified as accident (cracking, settling) and not as failure.

Figure 9 includes the graph prepared by Conlin (1987) and complemented by Lo et al. (1988) and Verdugo (2011), showing several of the upstream dams that have failed, 
and others that have not, according to the magnitude of the earthquake and the distance from the epicenter in the case of each dam, indicating a possible boundary between the two types of behaviour. However, distance from the epicenter in the case of the 2010 earthquake could be misleading, since this was a subduction earthquake with a very long $\mathrm{N}-\mathrm{S}$ plate rupture some $500 \mathrm{~km}$ in length along the coast. Consequently, if the distance from the plate rupture zone is taken into consideration for each of the dams that failed in Chile in the 2010 earthquake instead of their distance from the epicenter, the limit proposed by Conlin (1987) probably would be valid even for high magnitude events.

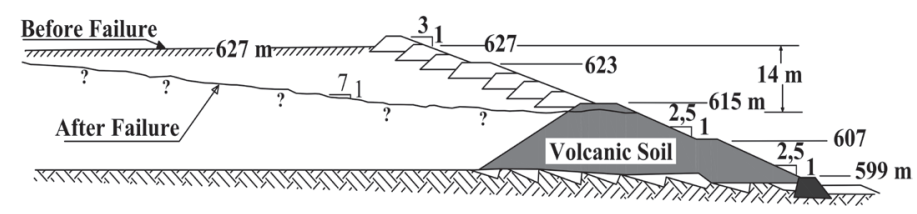

Figure 7: Cross-section through embankment of No. 1 dyke, Mochikoshi 1978 (Ishihara, 1984)

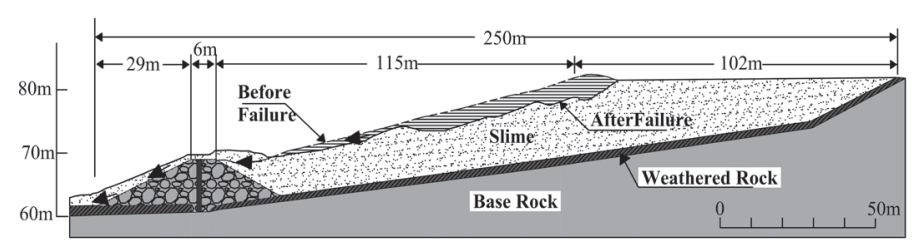

Figure 8: Cross-section of Kayakari tailings dam at Ohya mine before and after failure 2011 (Ishihara et al., 2015)

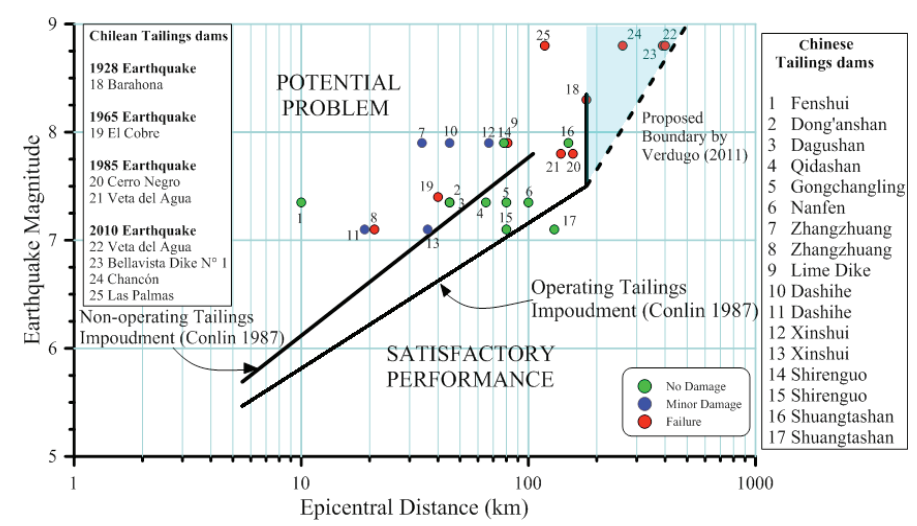

Figure 9: Susceptibility of upstream tailings dams to suffer damage due to earthquakes (Conlin, 1987; Lo et al., 1988; Verdugo, 2011)

Finn (1996), quoting Xin et al. (1992), notes that, regardless of the high total number of failures, statistics on China's upstream dams are more favourable, apparently because in China, the slopes of several of the downstream dams that had not failed during earthquakes were gentler, in the order of 1:4 to 1:5 (V: H), and because deposited sands had a lower concentration of solids - in the order of $20 \%$ in weight - to facilitate formation of those slopes. In Figure 9 a number of Chinese upstream tailings sand dams have been included as reference. It is clear that most of Chinese tailings dams which did not have any stability problems, are well to the left of the Conlin dividing lines. This difference is due to the different construction characteristics of the dams. In the case of Chile the dams that have failed were upstream sand dams with relatively steep downstream slopes, ranging between $1: 1.5$ and $1: 2(\mathrm{~V}: \mathrm{H})$.

Nevertheless, in spite of improvements that could be introduced into the design of upstream dams to improve their stability (Martin et al., 2002), their very nature makes them vulnerable to strong earthquakes, due to the risk of liquefaction of saturated sands and to the relatively weak undrained resistance of retained slimes. Additionally, this type of dam is more vulnerable to operational defects or operational failures than downstream or centerline dams. One example is the Main St. Joe upstream dam in the USA, where an investigation of its stability at the end of the dam's operation detected relatively thin lens of slime at halfheight, approximately at the 820 level (Figure 10), which was confirmed to control post-earthquake deformations. The analysis showed that, had that lens not been present, the dam would probably have remained stable for the design earthquake, in spite of the apparently more critical presence of loose sands above level 830 next to the dam body with $\left(\overline{\mathrm{N}}_{1}\right)_{60} \approx 8$ and of totally saturated surface slimes containing $75-90 \%$ of fines (Vick et al., 1993; Finn, 1996). This thin layer of slimes at the 820 level was probably the result of defective operation. This is a clear example of the vulnerability of this type of dam to negligence or lack of control in operation, a risk that is also associated with the extended period of construction of such dams.

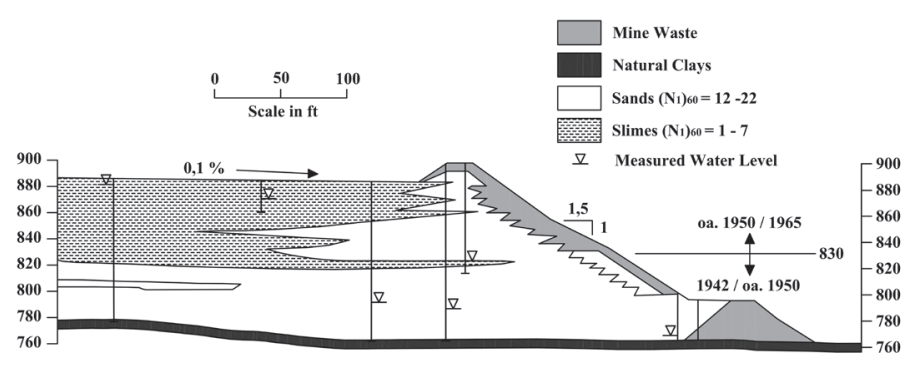

Figure 10: Section of the Main St. Joe tailings dam (Vick et al., 1993, Finn, 1996) 
In Chile, after the disastrous failure of El Cobre $\mathrm{N}^{\circ} 1$ in 1965 , the government agency in charge of granting permits for new tailings dams prohibited the construction of dams using the upstream method beginning in 1970, unless a specific permit had been issued by the national director of that agency for very extraordinary conditions MM (1970). Later, Decree DS 248 (MM, 2007) confirmed the prohibition of tailings dams constructed using the upstream method with no exceptions.

\section{Major tailings sand dams after 1965}

After the El Cobre $\mathrm{N}^{\circ} 1$ failure with its more than 200 victims, the year 1965 became a turning point in the conception and design of tailings dams in Chile. Regulatory agencies and the mining industry reacted by eliminating the option of upstream dams and adopting other solutions such as downstream tailings sand, waste rock-fill, and conventional earth dams whenever feasible, in spite of higher costs of initial investment, operating cost, and deferred investment than upstream tailings dams. Table 1 lists the major tailings dams constructed after 1965 by the copper industry, which currently treats by concentration and flotation approximately 2.5 million tons of ore daily, representing a similar figure in tons of dry tailings (some 97 to $98 \%$ of the total treated ore). These tailings must be deposited daily, generally in concentrations of solids by weight $C_{\mathrm{p}}$ ranging between 35 and $55 \%$, in a safe manner and in compliance with environmental standards and requirements. All the important dams constructed after 1965 for the medium-scale and large-scale mining industry $^{2}$ (sectors that have adequate organizational structures to handle tailings deposits and especially to construct and operate their dams), included those listed in Table 2, have performed satisfactorily, including many that were subjected to relatively close major seismic events $(M>7.0)$. Only the Piuquenes dam (around 1970) and the Pérez Caldera $\mathrm{N}^{\circ} 2$ dam (1978) have suffered some accidents, though finally without serious consequences. In Piuquenes, there were problems with the impoundment drainage system, which were later repaired, including reinforcement of the dam. Pérez Caldera $\mathrm{N}^{\circ} 2$ dam had an accident in the water diversion tunnel, causing an emergency situation that was resolved in a timely manner.

\footnotetext{
${ }^{2}$ Medium-scale mining in the order of $5000 \mathrm{t} /$ day; large-scale mining greater than 30000 t/day
}

Table 1: List of Chilean tailings dams post-1965

\begin{tabular}{|c|c|c|c|c|c|c|}
\hline Name & $\begin{array}{c}\text { Max. } \\
\text { height, } \\
\mathrm{m}\end{array}$ & $\begin{array}{l}\text { Dam } \\
\text { length, } \\
\text { m }\end{array}$ & $\begin{array}{c}\text { Capacity, } \\
\operatorname{Mm}^{3}(+)\end{array}$ & $\begin{array}{c}\text { Initiation } \\
\text { of } \\
\text { operation }\end{array}$ & Type & $\begin{array}{c}\text { End of } \\
\text { opera- } \\
\text { tion }\end{array}$ \\
\hline El Cobre $4^{*}$ & 68 & 1140 & 31 & 1969 & DS & 1992 \\
\hline Pérez C. 2* & $\begin{array}{c}115- \\
135 \S\end{array}$ & 500 & 84 & 1978 & DS & 1992 \\
\hline El Chinche & 100 & 470 & 14.5 & 1992 & DS & 1999 \\
\hline $\begin{array}{l}\text { Las } \\
\text { Tórtolas* }\end{array}$ & $\begin{array}{l}150- \\
170 \\
\end{array}$ & $\begin{array}{c}1700 \\
(-)\end{array}$ & 1000 & 1992 & DS & OP \\
\hline Torito* & 78 & 2190 & 130 & 1992 & $\begin{array}{l}\text { DS/ } \\
\text { CL }\end{array}$ & OP \\
\hline Quillayes & $\begin{array}{l}175- \\
198\end{array}$ & $\begin{array}{c}1600 \\
(+)\end{array}$ & 253 & 1999 & DS & 2009 \\
\hline Ovejería* & 130 & $\begin{array}{c}5000 \\
(+)\end{array}$ & 1380 & 1999 & DS & OP \\
\hline El Mauro & 237 & 1450 & 1088 & 2009 & DS & OP \\
\hline Piuquenes* & 58 & 500 & 20.5 & 1970 & DS & 1980 \\
\hline Talabre & $>50$ & $>10000$ & $>1200$ & 1985 & $\begin{array}{l}\mathrm{EF} / \\
\mathrm{DS}\end{array}$ & OP \\
\hline P. Pabellón & $90 \S$ & $\begin{array}{c}4500 \\
(+)\end{array}$ & 2400 & 1998 & $\mathrm{RF}$ & OP \\
\hline $\begin{array}{l}\text { Pampa } \\
\text { Austral }\end{array}$ & 29 & 700 & 100 & 1989 & $\mathrm{EF}$ & OP \\
\hline El Indio & 79 & 290 & 4,2 & 1987 & $\mathrm{EF}$ & 1999 \\
\hline Los Leones* & 160 & 500 & 140 & 1980 & $\mathrm{RF}$ & 1999 \\
\hline Colihues A* & 83 & 1200 & 160 & 1981 & $\mathrm{EF}$ & 1986 \\
\hline Candelaria & 163 & 2400 & 281 & 1995 & $\mathrm{RF}$ & OP \\
\hline Carén* & $>70$ & 950 & 300 & 1986 & $\mathrm{EF}$ & $\mathrm{OP}$ \\
\hline
\end{tabular}

Note: the figures are approximated, obtained from different sources. Some of the deposits have been expanded, not all of them registered in this table.

(-) only main dam; § approximate final height; $(+)$ approximately;

* dams located in Chile's central zone; DS: Downstream sand dam;

CL: Centerline sand dam; RF: Rock-fill; EF: Earth-fill

These last two cases confirm the importance of operation and maintenance for the safety of dams. Table 1 highlights dams constructed with tailings sands (grey background), all of which are of downstream construction DS, with the exception of Torito, which began as downstream and was changed at a certain time during construction to centerline CL. Some of these dams have attained important heights, such as the Quillayes dam, which recently ended operations after reaching a height of $198 \mathrm{~m}$ (measured vertically below crest).

Tailings dams of any type located in Chile's central zone, and therefore in the impact zone of the 2010 Maule earthquake $\left(\mathrm{M}_{\mathrm{w}}=8.8\right)$, have been identified with an asterisk on Table $1(*)$. It is remarkable that although these 
dams were only between 100 and $160 \mathrm{~km}$ from the plate rupture zone (Troncoso, 2014), none of them suffered any significant damage.

In the section below, we describe and discuss two Chilean downstream tailings sand dams that are representative of Chilean practice.

\section{Las Tórtolas main dam}

Las Tórtolas tailings deposit is located at an elevation of 700 masl, $45 \mathrm{~km}$ north of Santiago, in Chile's central valley (Valenzuela, 1996). Studies of this dam, initiated in 1984, analyzed in detail the experience gained up to that date in El Cobre $\mathrm{N}^{\circ} 4$ and Pérez Caldera $\mathrm{N}^{\circ} 2$. The adopted design included a maximum final height of $150 \mathrm{~m}$, some $30 \mathrm{~m}$ higher than Pérez Caldera $\mathrm{N}^{\circ} 2$. In this dam, shown in cross section in Figure 11, conservative original design criteria included a double cyclone station to guarantee $10 \%$ maximum fines content $\mathrm{FC}$ in the sand. The design considered the implementation of a network of instruments, including piezometers and accelerometers. This is the first dam that was subjected to a dynamic stability and deformational analysis using the finite differences method (DSAG at the time, which later gave birth to FLAC). Satisfactory performance of this dam, which began operating in 1992, made it possible to increase $\mathrm{FC}$ to $15 \%$ a few years later and to define a new maximum height of $170 \mathrm{~m}$. The current height of this dam is about $90 \mathrm{~m}$. Design of this deposit initially set a maximum capacity of 1000 million tons of tailings, and recent estimates increased that capacity to 2000 million tons. The deposit has two other smaller cycloned sand dams, all constructed using the downstream method. In the main dam, the starter dam consists of compacted earth $17 \mathrm{~m}$ high. Approximately $5 \mathrm{~m}$ of loose alluvial soil were excavated under the starter dam and under part of the sand dam, after which dynamic compaction was applied to the foundation. The rest of the foundation consists of denser gravelly sands. The downstream slope of the starter dam was constructed with a very shallow gradient in order to facilitate initial deposition of sands. The dam is equipped with generous basal drains that were built in stages. The dam was constructed with cycloned sands and compacted to $95 \%$ Proctor Standard. The sand was initially deposited forming a slope of 1:4 (V:H). After a few years of operation, and after verification of very satisfactory dam performance confirmed by density controls and piezometric level records, the deposition slope was changed to 1:3.5 (V:H). A final slope of $1: 3(\mathrm{~V}: \mathrm{H})$ is considered for the closure stage.

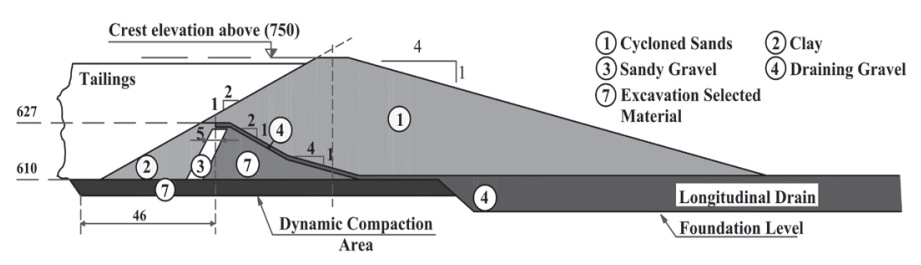

Figure 11: Cross-section of the main dam of the Las Tórtolas tailings deposit (Valenzuela, 1996)

Although this dam had not yet been built at the time of the Valparaíso earthquake of 1985, there were already accelerometers installed in rock at the dam site and the registers of this strong and relatively close earthquake were considered later in the dam dynamic stability analysis. Recently, the dam was subjected to the strong 2010 Maule earthquake, and its aftershocks. The distance from the epicenter was $360 \mathrm{~km}$ and $107 \mathrm{~km}$ from the rupture plate zone. No significant damage or deformation was observed. During this earthquake the installed geotechnical and seismological instrumentation recorded the accelerations at foundation level in free field conditions. During that seismic event, only an increase of the piezometric level was registered. This was measured in three piezometers located in the starter dam, showing an increase in piezometric level corresponding to 3 to $5 \%$ of the thickness of tailings above the starter dam, levels which recovered within a short time (Illanes et al., 2015).

\section{Quillayes tailings sand dam}

The Quillayes tailings sand dam is of special interest, due to a series of conditions that translated into major design, construction, and operating requirements. The urgent need for a site in which to deposit tailings for Los Pelambres mine expansion project, located $300 \mathrm{~km}$ north of Santiago at an elevation over 3100 masl, prompted the decision to construct the Quillayes deposit in the interior of the mining company's property in the vicinity of other mine facilities. The site was topographically challenging, consisting of a narrow valley that allowed only for a very low impoundment volume/dam ratio (3:1), in a relatively large hydrographic basin $\left(250 \mathrm{~km}^{2}\right)$ that required water diversion works including a $40 \mathrm{~m}$ high compacted earth dam and a $5 \mathrm{~km}$-long 
tunnel with a $30 \mathrm{~m}^{2}$ cross-section. The low impoundment/ dam ratio and the high daily production of tailings to be deposited, some $100000 \mathrm{TMPD}^{3}$, determined the need for a 70 m-high starter dam constructed of compacted clayish sandy gravel. It was necessary to cyclone $100 \%$ of the tailings to produce enough sand for the dam to grow at the rapid rate required during the early years, reaching a record $37 \mathrm{~m}$ above the starter dam crest during the first year. Given the narrowness of the valley, the initial years offered the greatest challenges to construction, arranging sands on the slope from sand pipelines at intermediate heights, and placing sands hydraulically at the foot of the dam via sub-horizontal cells. The cross-section of the dam is shown in Figure 12.

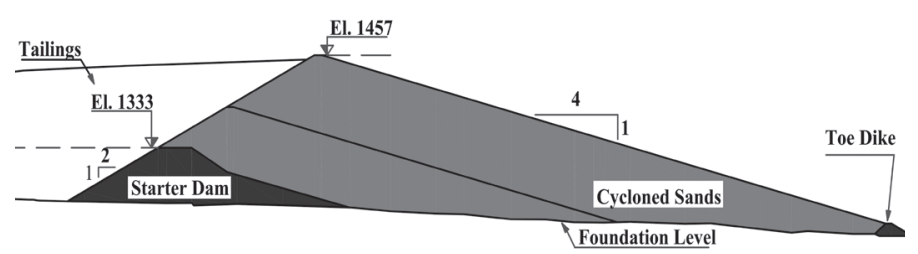

Figure 12: Cross-section of the Quillayes dam (Valenzuela and Campaña, 2014)

The dam foundation consists of $8 \mathrm{~m}$-thick fluvial deposits, colluvium deposits in the left abutment $(3 \mathrm{~m})$ and intrusive granodiorite rock in the right abutment. Soil deposits are of medium to high compaction, and considered not susceptible to liquefaction. Construction of this downstream tailings sand dam was begun in November 1998 and completed in July 2008, after deposition of close to 78 million $\mathrm{m}^{3}$ of sand to the dam's maximum height of $198 \mathrm{~m}$. Up to one million $\mathrm{m}^{3}$ of sand were deposited and compacted per month while the deposit was in operation. The tailings produced in the concentrate plant consisted of a sandy slime with $80 \%$ in weight of soil with a size of approximately 212 microns and $50 \%$ fines under 200 mesh. Sands were specified to contain a maximum of $18 \%$ fines, and up to a maximum of $20 \%$ of samples were accepted with a content of maximum $20 \%$ fines. Sands were obtained from a fixed automated cyclone station installed at a convenient height on the right abutment of the dam, consisting of two sets or clusters of 20 cyclones each, which have been shown in Figure 2. Another interesting characteristic of this dam is that construction and operation were undertaken in their totality by a consortium that included the firm responsible for the

\footnotetext{
${ }^{3}$ TMPD: tons of mineral per day.
}

design of the dam, representing a remarkable example of operation by a specialized outsourced company that included permanent geotechnical support during operation (Valenzuela et al., 2013). In 2002, the mining company commissioned a technical audit of the dam construction that included SPT and SCPT drillings, seismic refraction profiles, and test pits to determine density, permeability, and resistance of the dam sands (Swaisgood, 2002). Geotechnical characteristics of the deposited sands and of the pertinent design criteria are shown in Table 2.

Since the year 2008, the deposit has no longer received tailings and has acted as an emergency impoundment between the concentrate plant and the new El Mauro tailings deposit. This dam was subjected in 16th September 2015 to the $M_{\mathrm{w}} 8.4$ Illapel earthquake with epicenter about $100 \mathrm{~km}$ from the dam. No damage or deformations of significance were observed in the dam.

Table 2: Comparison of geotechnical design and construction parameters (Valenzuela and Barrera, 2003)

\begin{tabular}{|l|c|c|}
\hline Parameter & Original design & Revision \\
\hline Relative density, $\%$ & 59 & 60 \\
\hline Friction Angle, $^{\circ}$ & $35-35.7$ & 35 \\
\hline CRR $^{\text {a }}$ & 0.21 & 0.24 \\
\hline $\begin{array}{l}\text { Average FC, } \% \\
\text { below\#200 }\end{array}$ & 15 & 16 \\
\hline Permeability, cm/s & $10^{-3}-10^{-4}$ & $10^{-3}-10^{-4}$ \\
\hline Phreatic level, ${ }^{\mathrm{b}}$ & 10 & $<10$ \\
\hline
\end{tabular}

${ }^{\mathrm{a} C y c l i c}$ Resistance Ratio, ${ }^{\mathrm{b}}$ for dynamic analysis purposes

The experiences of the Las Tórtolas dam and of the 100 m-high downstream El Chinche dam, which was already operating at the Los Pelambres mine, supported the feasibility of a height of $175 \mathrm{~m}$ for the Quillayes dam, $25 \mathrm{~m}$ higher than Las Tórtolas. The Quillayes dam had the benefit of having sand from the El Chinche dam, which came from the same mine ore. This made it possible to conduct tests at high pressures, using sands that were representative of the actual operation rather than pilot plant sands. In this case, FLAC 3D was applied for the first time in dynamic analysis of a tailings dam (Swaisgood, 2002). The excellent performance of the initial dam made it later possible to adopt a maximum height of $198 \mathrm{~m}$. It must be pointed out that the Quillayes and El Chinche experiences formed, in turn, the basis for the design of 
the new El Mauro dam, constructed to store tailings from the Los Pelambres mine, to a maximum height of $237 \mathrm{~m}$. Additional geotechnical tests were conducted for the El Mauro dam in sands subjected to high confinement pressures. Analysis of the behaviour and failure of tailings dams confirms that tailings sand dams constructed using the downstream method are safe even when they attain great height and are subjected to severe seismic conditions, provided they are adequately designed, constructed, and operated. The characteristics that have largely explained the good performance of downstream dams during the past four decades in a country as highly seismic as Chile are:

- Strict control of FC in sands in order to guarantee high permeability, and consequently a significant contrast of permeability between the contained tailings or slimes and the sand.

- Compaction of sands, generally over $95 \%$ of Standard Proctor density. The confirmation, based on the measurements from piezometers installed in several downstream tailings dams as well as the relatively high and consistent drained strength of tailings sands even under high confining pressures, indicate that this compaction could not be necessary after the dam has reached a certain height (Valenzuela, 1996).

- Downstream slope of 1:3.5 to $1: 4(\mathrm{~V}: \mathrm{H})$, to facilitate compaction and to reduce stress concentration on the foundations.

- Capacity of basal drains designed conservatively, covering a significant percentage of the foundation area, allowing for possible break-up of particles and compressibility accordingly to tension levels.

- Treatment of the foundation, eliminating or compacting soils that can potentially suffer liquefaction.

- Clear water pond of minimum volume, located distant from the dam.

- Lining of the upstream slope, with a waterproof membrane to protect the body of sand from eventual floods.

- Conservative criteria for definition of the freeboard, accounting for deformations, floods, and earthquake settlement for the operating and closure scenarios.

- Robust and reliable water diversion system to handle floods.
- Adequate design and verification of dam stability, under both seismic and static conditions, during the beginning of the operation and in intermediate stages.

Stability of the dams depends also on the adequate design of all their components, such as foundation treatment, drainage system, filters, and ancillary hydraulic works, in accordance with best engineering and geotechnical practices. The dam design must be included in the global design of the deposit, with special consideration for an adequate and conservative water management system, including the necessary water flood control and water recovery systems within the deposit to take care of water accumulated in the clear water pond. Overtopping has been the cause of failure of many dams included in the international statistics (Conlin, 1987; Lo et al., 1988), this been the reason to carefully consider all aspects of water management within the deposit. These tailings sand dams need to be constructed and operated precisely according to their design criteria, and dam performance must be monitored and recorded throughout their operational and post-operational periods. Other special aspects such as possible tailings acid generation and ground water infiltration, are not encompassed in this paper.

\section{Trend to increase the height of tailings dams}

Mining worldwide, and particularly copper mining, has experienced remarkable growth between years 2000 and 2012. This has resulted in projects with high daily production rates. In countries like Chile and Peru, the world's largest copper producers (both countries together are responsible for the $40 \%$ of global production ${ }^{4}$ ), several of these projects are located in the Andes mountain range high above sea level, necessitating the construction of large tailings deposits, many of which require dams of considerable height.

In addition to the Chilean dams shown in Table 1, Cerro Verde centerline sand dam in Peru will reach a maximum height of $260 \mathrm{~m}$ (Obermeyer and Alexieva, 2011). In Canada, the Thompson Creek dam, also centerline, will have a maximum height of $220 \mathrm{~m}$ and in the USA the Highland Copper Valley centerline dam will be $169 \mathrm{~m}$ high (Scott et al., 2007). Other tailings sand dams currently under study

${ }^{4}$ Percentage estimated on basis of average production in the period 2004 to 2013 (Cochilco, 2014) 
in South America would have final heights of over $300 \mathrm{~m}$. The dam height indicated is the measurement of vertical distance between the dam crest and its foundation. If the ICOLD definition is used, where the height is measured as the difference in elevation between the crest and the downstream toe, larger heights could result. This worldwide trend, a result of growing production levels in large-scale mining, presents a great challenge to dam engineering, and especially to geotechnical engineering. An interesting process was followed in Chile in the design of tailings sand dams after the failure of Cobre $\mathrm{N}^{\circ} 1$ in 1965: it began at El Soldado mine with El Cobre $\mathrm{N}^{\circ} 4$ downstream sand dam. In this process, the performance and experience gained with each dam constructed after 1965 have improved the design and operation of subsequent projects using tailings sands with different FC and confining pressures. This process has also benefited from the information obtained from instrumentation, especially from piezometer data, which confirmed the advantages of FC control in sand permeability showing basically unsaturated sand dams, with the exception of minor zones in the dam base in contact with the basal drain system (Illanes et al., 2015). Even though the number of failures of downstream or centerline tailings dams worldwide is relatively very low, the trend towards dams of great height increases the impact of any eventual failure. Design, construction, and operation of these dams must therefore be extremely careful and conservative. Construction of very high tailings sand dams requires careful analysis of the following characteristics: the behaviour of granular soils subjected to high confining pressures; the potential of static liquefaction; the validity of stability and deformation analyses under strong seismic conditions; and the necessity for important control activities during extremely long construction, operation and post-operation periods.

\section{Geotechnical behaviour of granular soils under high confining pressures}

The great height of some dams makes it imperative to assess the impact of high confinement pressures on the behaviour and geotechnical properties of the granular materials that constitute the dam, such as the permeability, compressibility, and shear resistance of the sands. The compressibility and permeability characteristics of gravel and rock-fill subjected to high confining pressures are also important, given that these materials form part of the structure of the basal drains of these dams. The results of testing conducted on samples of porphyry copper tailings of the Andes Mountains of Chile and Peru, as well as on mining waste rock and coarse alluvial soil samples from Chile are presented below. The sands tested come from five mining processes (one of them a pilot plant). Tórtolas sand $\mathrm{S} 1$ comes from the tailings dam of the same name. Two of the remaining samples, $\mathrm{S} 2$ to $\mathrm{S} 5$, come from operations in Chile and two from operations in Peru. The mineralogical characteristics presented in Table 3 may be considered representative of these sands.

\section{Permeability of sands}

Permeability of sands and the hydraulic capacity of the basal drains are key properties for dam stability. Downstream and centerline dams are designed to prevent saturation of the sandy body of the, or at least to limit saturation to a very restricted zone at the base of the dam, where there must be a generous network of basal drains to prevent the phreatic level from exceeding design conditions. Adequate design of this type of dam requires that sand permeability exceed permeability of the deposited tailings and/or slimes in contact with the dam by two to three orders of magnitude, guaranteeing that the flow of water from the deposited tailings and from the water used for transport and deposition of sands will be as close as possible to the gravitational flow within an unsaturated medium, thus reaching the basal drains quickly. Vick (1983) shows that the greater the contrast in permeability between sands and tailings or slimes, the lower the phreatic level that will be maintained. Following are the results of seepage analysis specifically done in a tailings sand dam with a cross section according to common practice in Chile on this type of dam. Figure 13a shows the results for a case in which permeability of sands is 500 times the permeability of slimes (permeability of $10^{-6} \mathrm{~cm} / \mathrm{s}$ for slimes and $5 \cdot 10^{-4} \mathrm{~cm} / \mathrm{s}$ for sands), in addition to tenfold anisotropy of sands in the direction of the slope, confirming that the phreatic level increases to up to $18 \%$ of the maximum height (assuming that the foundation soil is impervious). Figure 13b shows the same example, but including a drainage system that covers $75 \%$ of the base of the dam. In this case, the phreatic level is only present in the upstream portion of the dam immediately where the basal drain begins, and up to a 
maximum height of the order of $0.05 \mathrm{H}$. The permeability values used in the models are typical of those seen in this type of material, as can be seen in Figure 15.

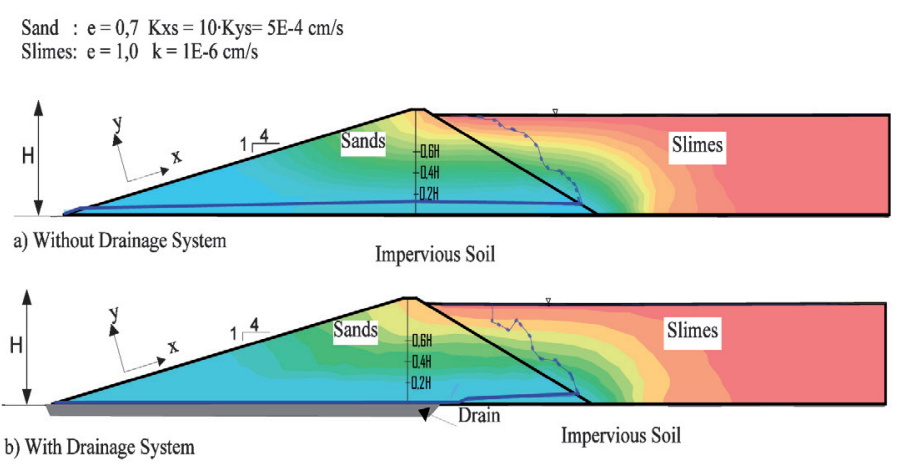

Figure 13: Flow network for a typical tailings dam cross-section showing phreatic level in blue line
The basal drainage must be designed with high safety factors (FS $\geq 10$ ) and be constructed with rigorous quality control. Maintaining a functional drainage system during the operating and closing stage is essential for the short and long-term stability of the dam, because low phreatic levels will enable drained behaviour of the sands and significantly reduce the liquefaction risk. Instruments installed in several dams in Chile confirm that all those dams show piezometric levels close to the top of the drains (Illanes et al., 2015).

One practical measure to ensure the required permeability is to limit non-plastic FC in the sands to a value that not only complies with the criterion of contrast with slimes,

Table 3: Mineralogical characteristics and index properties of sands from Chile and Peru (Campaña, 2011; Bard et al., 2014)

\begin{tabular}{|c|c|c|c|c|c|c|c|c|c|c|}
\hline \multirow{2}{*}{$\begin{array}{l}\text { USCS } \\
\text { Classif. }\end{array}$} & \multirow[b]{2}{*}{$\% \mathrm{FC}$} & \multirow[b]{2}{*}{$e_{\max }$} & \multirow[b]{2}{*}{$e_{\min }$} & \multirow[b]{2}{*}{$\mathrm{C}_{\mathrm{c}}$} & \multirow[b]{2}{*}{$\mathrm{C}_{\mathrm{u}}$} & \multirow[b]{2}{*}{$\begin{array}{l}d_{50} \\
\mathrm{~mm}\end{array}$} & \multicolumn{2}{|c|}{ MP } & \multicolumn{2}{|c|}{ SP } \\
\hline & & & & & & & $\begin{array}{l}\mathrm{MDD} \\
\mathrm{kN} / \mathrm{m}^{3}\end{array}$ & $w_{\mathrm{opt}}, \%$ & $\begin{array}{l}\mathrm{MDD} \\
\mathrm{kN} / \mathrm{m}^{3}\end{array}$ & $w_{\mathrm{opt}} \%$ \\
\hline \multicolumn{11}{|c|}{ Sand S1 - Las Tórtolas, $\mathrm{G}_{\mathrm{s}}=2.73$} \\
\hline SM & 15 & 1.100 & 0.460 & 1.4 & 3.3 & 0.167 & 16.78 & 14.0 & 15.89 & 18.0 \\
\hline SM & 18 & 1.068 & 0.444 & 1.5 & 3.6 & - & 16.97 & 14.0 & 16.38 & 16.0 \\
\hline SM & 21 & 1.084 & 0.414 & 1.0 & 4.0 & 0.154 & 17.36 & 12.5 & 16.38 & 16.0 \\
\hline \multicolumn{11}{|c|}{$\begin{array}{l}\text { Mineralogy: } 45 \% \text { quartz; } 30 \% \text { muscovite-sericite; } 15 \% \text { plagioclase; } 5 \% \text { opaque } \\
\text { minerals; } 4 \% \text { biotite; } 1 \% \text { other }\end{array}$} \\
\hline \multicolumn{11}{|c|}{ Sand $\mathrm{S} 2, \mathrm{G}_{\mathrm{s}}=2.67-2.75, \mathrm{G}_{\mathrm{s} \text { average }}=2.72$} \\
\hline SM & 15 & 1.310 & 0.647 & 1.2 & 1.7 & - & 16.68 & 10.0 & 15.30 & 14.0 \\
\hline SM§ & 15 & 1.068 & 0.517 & - & - & - & 17.07 & 12.8 & - & - \\
\hline SM§ & 18 & 0.992 & 0.537 & - & - & 0.164 & 16.88 & 13.8 & - & - \\
\hline SM & 21 & 1.331 & 0.571 & 1.2 & 1.8 & - & 16.87 & 11.0 & 15.99 & 18.0 \\
\hline \multicolumn{11}{|c|}{$\begin{array}{l}\text { Mineralogy: } 45 \% \text { quartz; } 42 \% \text { sericite; } 4 \% \text { iron oxide; } 3 \% \text { feldspars; } 3 \% \text { opaque } \\
\text { minerals; } 3 \% \text { biotite }\end{array}$} \\
\hline \multicolumn{11}{|c|}{ Sand $\mathrm{S} 3, \mathrm{G}_{\mathrm{s}}=2.70$} \\
\hline SM & 12 & 0.942 & 0.525 & 1.2 & 4.2 & 0.127 & 17.46 & 13.5 & 16.48 & 15.5 \\
\hline SM & 18 & 0.956 & 0.484 & 3.1 & 1.9 & 0.120 & 18.25 & 11.0 & 16.77 & 14.5 \\
\hline \multicolumn{11}{|c|}{ Sand $\mathrm{S} 4, \mathrm{G}_{\mathrm{s}}=2.69$} \\
\hline SM & 24 & 0.915 & 0.406 & 2.7 & 165 & - & 18.84 & 8.0 & 17.36 & 8.5 \\
\hline SM & 20 & 1.280 & 0.601 & 1.2 & 4.2 & 0.129 & 16.48 & 15.0 & 15.40 & 18.0 \\
\hline SM & 30 & 1.280 & 0.592 & 3.1 & 12.9 & 0.116 & 17.85 & 11.5 & 16.87 & 14.0 \\
\hline \multicolumn{11}{|c|}{ Mineralogy: $60 \%$ quartz; $15.5 \%$ muscovite; $18 \%$ albite; $2 \%$ kaolinite; $4.5 \%$ other } \\
\hline \multicolumn{11}{|c|}{ Sand S5, $\mathrm{G}_{\mathrm{s}}=2.88$} \\
\hline SM & 15 & 0.694 & 0.532 & 3.2 & 1.0 & - & 18.3 & 8.5 & 17.10 & 16.0 \\
\hline SM & 20 & 1.087 & 0.500 & 3.1 & 0.8 & - & 18.9 & 10.5 & 17.70 & 16.0 \\
\hline
\end{tabular}

$\%$ FC: particles $<0.074 \mathrm{~mm}, \mathrm{G}_{\mathrm{s}}$ : specific gravity, $\mathrm{C}_{\mathrm{u}}$ : coefficient of uniformity, $\mathrm{C}_{\mathrm{c}}$ : coefficient of curvature, MDD: Maximum Dry Density, MP: Modified Proctor Test, SP: Standard Proctor Test, $w_{\text {opt }}$ : optimum water content, $e_{\max }:$ maximum void ratio, $e_{\min }$ : minimum void ratio, $\S$ tested at low pressures, $\sigma_{3}{ }_{3}<0.8 \mathrm{MPa}$, USCS: Unified Soil Classif. System 
but also leaves enough of a safety margin to ensure proper drainage if tailings segregation provokes the formation of sectors with higher FC values, or if high confinement pressures generate higher contents of fines due to the breakup of particles. The relationship between permeability and percentage of fines is not quite as clear, or as general, as discussed below, but within the range of 10 to 25 - 30\% of FC, variations have been measured in the laboratory of up to one order of magnitude, as shown in Figure 14. Regulations in Chile, for example, for the design and construction of tailings sand dams require a $\mathrm{FC}$ in sands no greater than 20\% (MM, 2007). The most marked differences in permeability are seen in tailings with FC values above 30 to $40 \%$, probably as a result of a change in the structure of the soil skeleton, since coarse grains would not all be in contact and fines would then not only fill the spaces left by the skeleton of coarse grains but would also partly replace the grain-to grain-contact (see Figure 15).

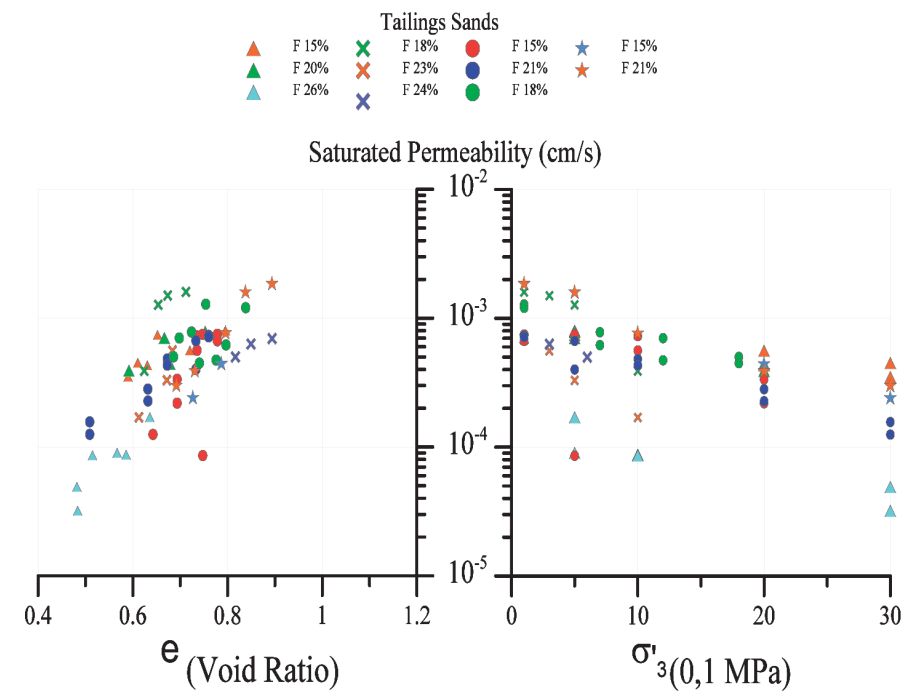

Figure 14: Permeability $k$ as a function of void ratio $e$ and confinement pressure $\sigma_{3}^{\prime}$, for several tailings sands with various contents of fines.

Figure 14 also shows in a very clear trend that permeability decline as confinement pressure is increased, making it possible for permeability to be reduced by up to one order of magnitude within the range of 0 to $3 \mathrm{MPa}$. This is generally addressed during the design stage when stability analyses are conducted, assuming a conservative saturation line in the lower part of the body of the dam, with a higher saturation line in the sectors with greater confinement pressure. Based on data in Figures 14 and 15, the dependence of permeability on the level of confinement pressure, as well as on the void ratio and relative density, is clear for the samples with FC levels between 15 and $30 \%$. However, Figure 15 shows that in samples with a higher $\mathrm{FC}$, in this case $30 \%$, the behaviour deviates from that of sands with a lower FC value, indicating a change in the structure of the sand skeleton. Permeability tests of sands with an FC value ranging between 15 and 23\% do not show substantial differences between them, leading to the determination of relatively high maximum $\mathrm{FC}$ values in some projects. However, that criterion does not leave enough leeway for eventual increases in the FC value due to segregation, break-up of particles, or variations in the particle size of sands, and eventually, in their mineralogy. It is therefore advisable to design with maximum FC well below $20 \%$. The current practice for tailings dams is to fix the percentage of fines between 15 and $19 \%$, and between 15 and 17\% for taller dams, which leaves a margin of safety for permeability variations and for the possible negative impacts of other factors. However, the results discussed herein indicate that specific permeability tests should be conducted during the different phases to confirm the parameters considered in the early studies, i.e., before construction, with samples from available sands or from pilot tests; during construction, with samples of sands produced during the construction and operation of the deposit and, each time there is a clear change in the characteristics of the tailings, such as grain size distribution, mineralogy, and chemistry.

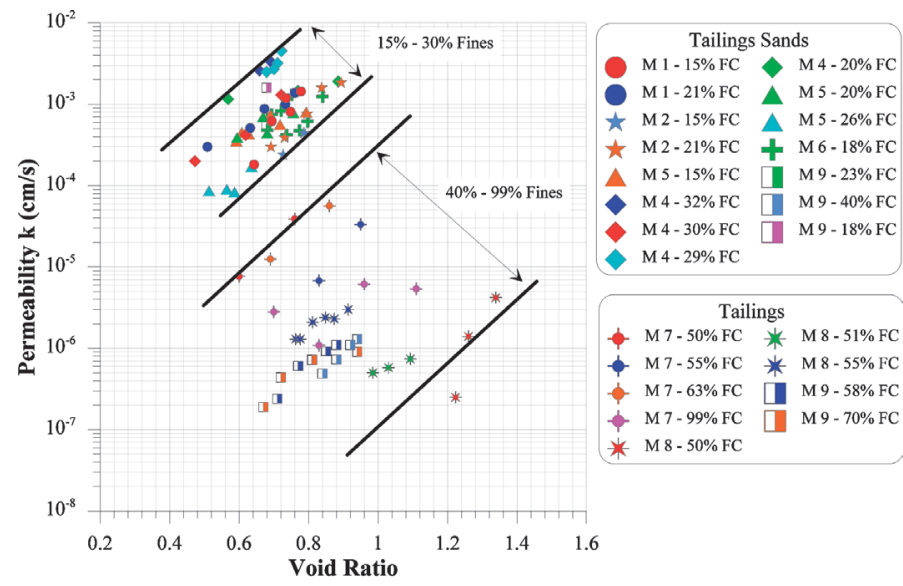

Figure 15: Permeability $k$ as a function of void ratio $e$, for typical tailings sands with various contents of fines (Campaña et al., 2015)

When determining the maximum $\mathrm{FC}$ value for tailings sands, the effect of particle segregation that occurs when the sands are deposited along the slope, an effect that can be 
more important in very tall dams, must be considered. This factor can become significant in some cases, causing a FC value increase of 2 to $3 \%$, as shown on Figure 16, which could require that the cyclone underflow have a lower FC value than the maximum design value, to compensate for the segregation effect (Figueroa et al., 2015).
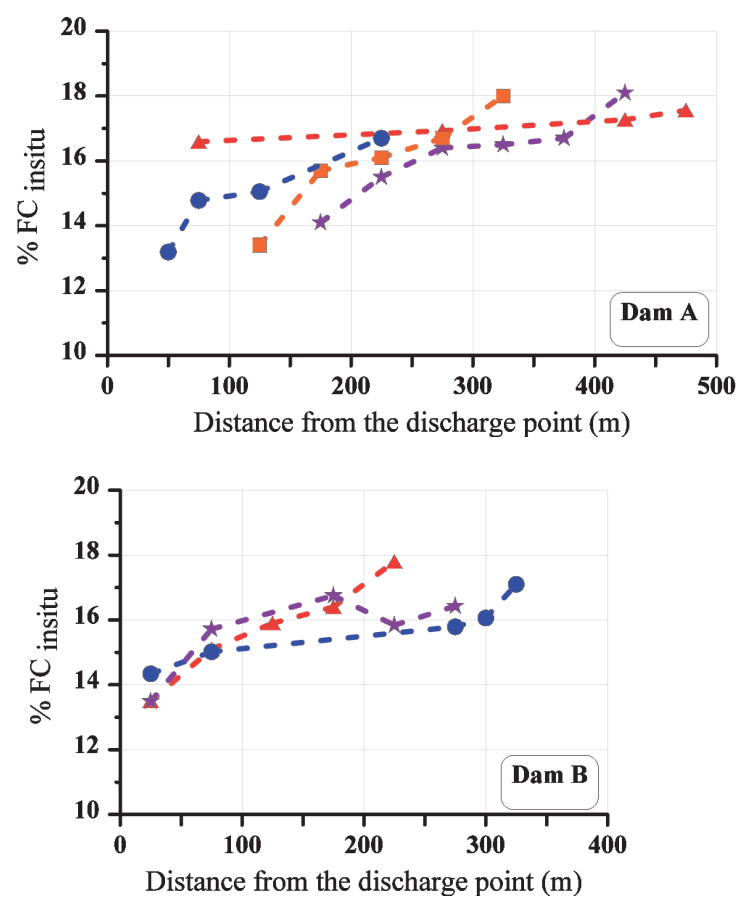

Figure 16: Fines segregation in sands deposited hydraulically in slopes of 1:3.5 to 1:4.0 (V:H) (Figueroa et al., 2015)

Production of sands with a maximum $\mathrm{FC}$ value requires a reliable and controllable operation that can be achieved, especially for high production levels, by processing the tailings in fixed industrial cyclone plants annexed to the dam in operation. This allows strict control of the FC of sands, in one or more cycloning stages or in one stage with cyclo-wash (water injection), or re-cycloning systems (with the addition of secondary cyclones). Mobile cyclone facilities can be installed and may perform satisfactorily on the crest of the dam as it grows, as in the case of Thompson Creek dam. However fixed stations should be installed whenever is possible to reduce operational risk and provide greater centralized control of the quality of produced sands (similar to a factory subject to strict specifications).

\section{Drained resistance of sands}

Bard et al. (2014) and Campaña et al. (2013) studied the behaviour of the tailings sands samples S1 to S5, identified in the legend of Figure 17 subjected to high confinement pressures. Figure 17 shows the shear resistance envelopes in the $q-p$ ' plane obtained from CID triaxial tests, and residual resistances obtained in CIU triaxial tests for the five tailings sands mentioned. In spite of the wide FC range of 12 to $30 \%$, the shear resistance envelopes turn out to be very similar. For $\sigma_{3}^{\prime}<1 \mathrm{MPa}$, the effective internal friction angle $\phi$ ' varies from $32^{\circ}$ to $36^{\circ}$, and for $\sigma_{3}^{\prime}>1$ $\mathrm{MPa}$, from $32^{\circ}$ to $34^{\circ}$. There is no significant degradation of drained resistance for high confinement pressures to which the sands were subjected. These results agree with those obtained with other sands of natural origin in which quartz mineral also dominates, such as Toyoura sand (Miura and Yamanouchi, 1975) and Ottawa sand (Murthy et al., 2007), with similar confinement pressures. The results, however, differ from the behaviour of Sacramento sand, which contains less quartz than the preceding sands (Lee and Seed, 1967).

a)

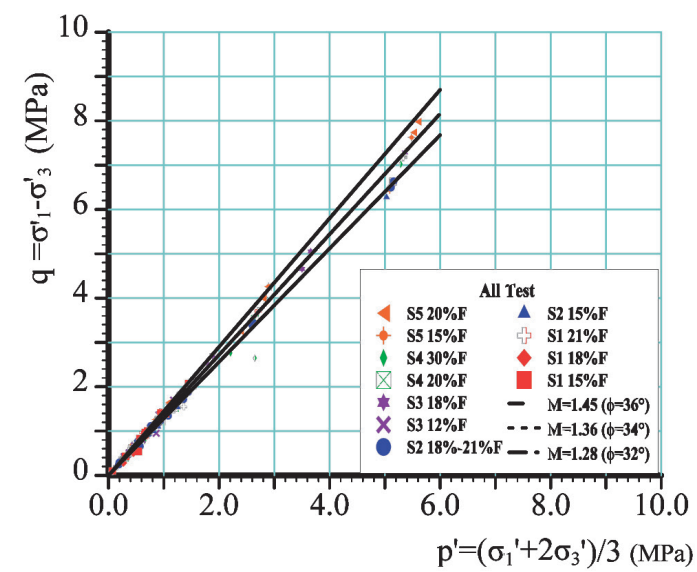

b)

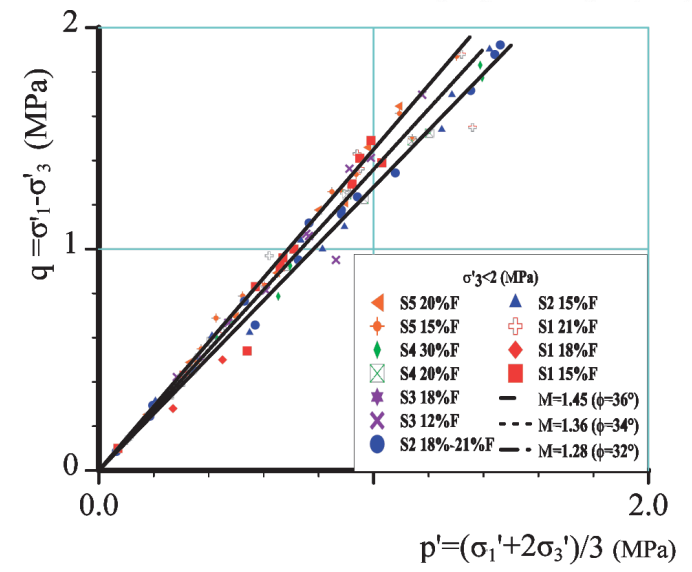

Figure 17: Drained shear resistance envelopes, a) total range of pressures and b) detail for $q<2 \mathrm{MPa}$ (Bard et al., 2014)

\section{Undrained resistance of tailings sands}

Figure 18 shows variations of undrained shear resistance $s_{\mathrm{u}}$ as a function of FC and of relative density $D_{\mathrm{R}}$ obtained 
at the end of the isotropic consolidation phase of the test specimen. The figure shows the average trends of the tested samples, compared with the trend obtained in Toyoura sand with $0 \%$ fines (Verdugo, 1992), Tía Juana silty sand with 15\% fines (Ishihara, 1993), and Lagunillas sandy silt with $80 \%$ fines, all of them for a wide range of relative densities. Sands with $30 \%$ of fines, would require a much higher density than the one required by sands with a FC between 12 and 21\%, apparently confirming the results of other tests showing that, over a certain FC value, of 25 to $30 \%$, there would be a change in structure of the granular skeleton of the soil.

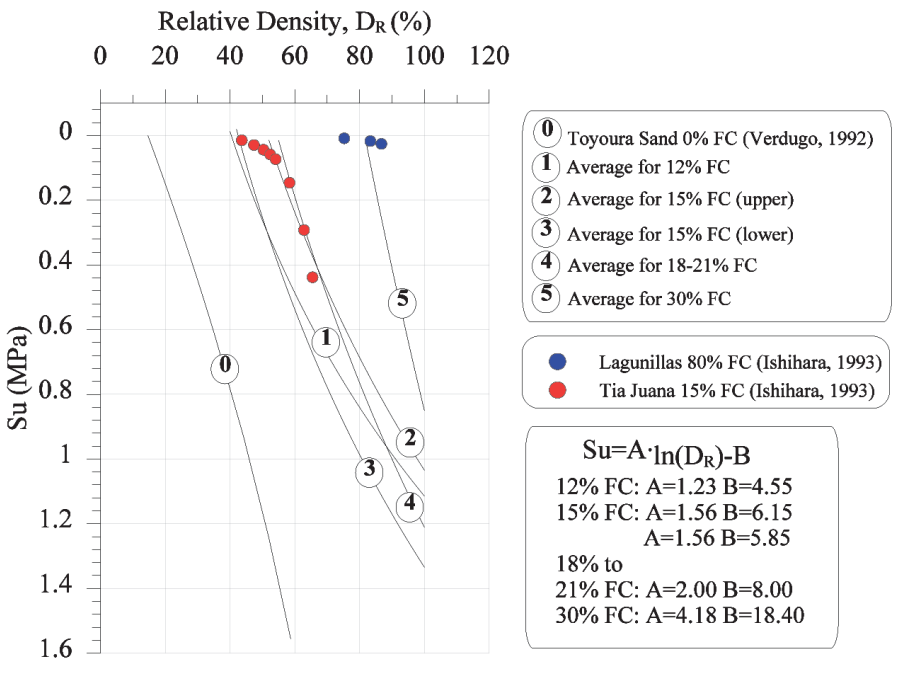

Figure 18: $s_{u}$ as a function of content of fines and comparison with the results of Toyoura sand (adapted from Bard et al., 2014)

\section{Final comments and conclusions}

Most of the failures of tailings sand dams correspond to specific designs that do not consider adequately the geotechnical characteristics of saturated or close to saturation sands that are subject to seismic loads and in some cases to static loads that could induce undrained responses of those sands. This has been the case, for instance, upstream tailings sand dams in seismic countries.

The basic concept behind a proper design, construction and operation of downstream tailings dams is the use of sands, generally compacted, more permeable than the contained tailings and slimes, with strict control of maximum nonplastic FC percentage, in addition to basal drains with sufficient capacity to safely evacuate water seeping through, thus minimizing the saturation zone within the dam. These same concepts also apply to dams constructed using the centerline method, with special attention to the upstream slope and crest width in the event of major seismic stresses.

The stability of dams depends on the adequate design of all their components, such as the main body, foundation treatment, drainage system, filters, and ancillary hydraulic works, in accordance with criteria, principles and best engineering and geotechnical practices. The construction and operation dams must adhere strictly to the design criteria. Dam performance must be monitored and recorded throughout its entire operating and post-operating periods.

\section{Acknowledgements}

The author wishes to acknowledge the support given by ARCADIS Chile and especially the collaboration and contributions of Edgar Bard, Jose Campaña, Abraham Figueroa and Jaime Urquidi in the preparation of this document. The author also wishes to express his thanks for the valuable comments and recommendations received from Ingo Fox, Arsenio Negro, Ricardo Nicolau, Caius Priscu, Jorge Troncoso and Ramon Verdugo. This paper is partially based on the Casagrande Lecture presented by the author in November 2015 (Valenzuela, 2015).

\section{References}

Agüero, G. (1929). Formación de depósitos de relaves en el mineral de El Teniente. Anales del Instituto de Ingenieros de Chile 5, 164-187

Bard, E. Campaña, J. Torres, P. Valenzuela, L. y Cifuentes, L. (2014). Comportamiento de arenas a altas presiones de confinamiento: comparación entre arenas de relaves y naturales. VIII Congreso Chileno de Geotecnia, Santiago

Blight, G.E. (2010). Geotechnical engineering for mine waste storage facilities. Taylor \& Francis

Campaña, J. Carmi, C. Bard, E. and Valenzuela, L. (2015). Permeability and consolidation parameters in tailings treated with seawater. XV Pan-American Conference on Soil Mechanics and Geotechnical Engineering, Buenos Aires

Campaña, J., Bard, E. and Verdugo, R. (2013). Shear strength and deformation modulus of tailing sands under high pressures. Proceedings of the $18^{\text {th }}$ Conference on Soil Mechanics and Geotechnical Engineering, Paris 
Campaña, J. (2011). Comportamiento de arenas de relave a altas presiones. Tesis MSc, Universidad de Chile

Castro, G. and Troncoso, J.H. (1989). Seismic behavior of three tailings dams during the March 3, 1985 Earthquake. 5th Chilean Conference on Seismology and Earthquake Engineering, Santiago

Cochilco (2014). Anuario de Estadísticas del Cobre y otros Minerales 1994 - 2013. Comisión Chilena del Cobre

Conlin, B. (1987). A review of the performance of mine tailings impoundments under earthquake loading conditions. Proceedings of the Vancouver Geotechnical Society Seminar on Earthquake

Davies, M.P. Martin, T.E. and Lighthall, P. (2000). Mine tailings dams: when things go wrong. Tailings Dams 2000, Association of State Dam Safety Officials, U.S. Committee on Large Dams, 261-273

Dobry, R. and Alvarez, L. (1967). Seismic failure of Chilean tailings dams. Journal of the Soil Mechanics and Foundations Division 93(6), 237-259

Figueroa, A., Valenzuela, L., Sconagmillo, C., Santos, E. and Tascón, A. (2015). Particle - size segregation in sand tailings dams. XV Pan-American Conference on Soil Mechanics and Geotechnical Engineering, Buenos Aires

Finn, W. D. L. (1996). Seismic design and evaluation of tailings dams: state of the art. Proceedings International Symposium on Seismic and Environmental Aspects of Dams Design: Earth, Concrete and Tailings Dams, ICOLD - ISSMFE, Chilean Geotechnical Society, 7-34

ICOLD (2001). Tailings dams - risk of dangerous occurrences. Bulletin 121

ICOLD (1995). Dam failure statistical analysis. Bulletin 99

Illanes, J., Urquidi, J., Figueroa, A., Campaña, J. and Morales, F. (2015). Geotechnical instrumentation in tailings sand dams. $X V$ Pan-American Conference on Soil Mechanics and Geotechnical Engineering, Buenos Aires

Ishihara, K. (1984). Post-earthquake failure of a tailings dam due to liquefaction of the pond deposit. Proceedings of the International Conference on Case Histories in Geotechnical Engineering, St. Louis, Missouri, 3, 1129-1143

Ishihara, K. (1993). Liquefaction and flow failure during earthquakes. Géotechnique 43(3), 351-451
Ishihara, K. Ueno, K. Yamada, S. Yasuda, S. and Yoneoka, T. (2015). Breach of a tailings dam in the 2011 earthquake in Japan. Soil Dynamics and Earthquake Engineering 68, 3-22

Lee, K.L. and Seed, H. (1967). Drained strength characteristics of sands. Journal of Soil Mechanics and Foundation Division 93(6), 117-141

Lo, R.C. Klohn, E.J. and Finn, W.D.L. (1988). Stability of hydraulic sandfill tailings dams. In Hydraulic Fill Structures, ASCE Geotech. 21, 549-572

Martin, T.E, Davies, M.P., Rice, S., Higgs, T. and Lighthall, P.C. (2002). Stewardship of tailings facilities. Mining, Minerals and Sustainable Development No. 20. International Institute for Environment and Development

Miura, N. and Yamanouchi, T. (1975). Effect of water on the behavior of quartz-rich sand under high stresses. Soils and Foundations 15(4), 23-34

MM (2007). Decreto Supremo No 248. Reglamento para la aprobación de proyectos de diseño, construcción, operación y cierre de los depósitos de relaves. Ministerio de Minería de Chile MM (1970). Decreto Supremo $N^{\circ}$ 86. Reglamento de construcción y operación de tranques de relaves. Ministerio de Minería de Chile

Murthy, T. Loukidis, D. Carrasco, J. Prezzi, M. and Salgado, R. (2007). Undrained monotic response of clean and silty sands. Géotechnique 57(3), 273-288

Obermeyer, J. and Alexieva, T. (2011). Design, construction and operation of a large centerline tailings storage facility with high rate of rise. Proc. Tailings and Mine Waste, Vancouver

Peck, R.B. (1980). Where has all the judgement gone?. The $5^{\text {th }}$ Laurits Bjerrum Memorial Lecture. Canadian Geotechnical Journal 17(4), 584-590

Priscu, C. (2014). Seguridad de presas y geotecnia - Áreas interrelacionadas. Presentation at the VIII Congreso Chileno de Ingeniería Geotécnica, Santiago

Ramirez, N. (2010). Effects of the 2010 earthquake on tailings disposals located on the South-Central Chile and its relation with Decreto 248. Seminar: Proposals for the operation of tailings disposals according to recent experiences, 2010 (in Spanish) 
Scott, M.D., Lo, R.C. and Thavaraj, T. (2007). Use of instrumentation to safeguard of tailings dams. $7^{\text {th }}$ International Symposium on Field Measurements in Geomechanics, ASCE, 1-13

Swaisgood, J. (2002). Investigation and evaluation of Quillayes dam. High Density and Past Seminar, Santiago, Chile

Troncoso, J.H. (2015). Personal communication to L. Valenzuela, June 2015

Troncoso, J.H. (2014). Seismic design of tailings dams - State of practice in South America. In Workshop of Seismic Design of Tailings Dams, $34^{\text {th }}$ USSD Annual Meeting and Conference, San Francisco

Troncoso, J.H., Avendaño, A. and Vergara, A. (1993). The seismic failure of Barahona tailings dam. 3rd International Conference on Case Histories in Geotechnical Engineering, 1473-1479

USCOLD (1994). Tailings dams incidents. USCOLD Committee on Tailings Dams

Valenzuela, L. (2015). Tailings dams and hydraulic fills. Casagrande Lecture, XV Panamerican Conference on Soil Mechanics and Geotechnical Engineering, Buenos Aires

Valenzuela, L. (2010). Chile earthquake and its impact on infrastructure. Congresso Brasileiro de Mecánica dos Solos e Engenharia Geotecnica, Brasil

Valenzuela, L. (1996). Main characteristics of large tailings dams. In Large Dams in Chile, ICOLD Chile annual meeting of ICOLD International, Santiago

Valenzuela, L. and Campaña, J. (2014). Sand tailings dams in Chile and its evolution since 1965. $2^{\text {nd }}$ International Seminar on Tailings Management, Antofagasta, Chile
Valenzuela, L., Alemparte, R. and Nicolau, R. (2013). Outsourcing of tailings operations: a successful case. $1^{\text {st }}$ International Seminar on Tailings Management, Santiago, Chile

Valenzuela, L. and Barrera, S. (2003). Seismic design of Los Quillayes tailings dams in Chile. XII Panamerican Conference on Soil Mechanics and Geotechnical Engineering, Cambridge, USA

Verdugo, R. (2011). Seismic stability analysis of large tailings dams. Proceedings 5th International Conference on Earthquake Geotechnical Engineering, Santiago, 359-383

Verdugo, R. (1992). Characterization of sandy soil behavior under large deformation. $\mathrm{PhD}$ thesis, University of Tokyo

Vick, S.G., Dorey, R., Finn, W.D.L. and Adams, R.C. (1993). Seismic stabilization of St. Joe State Park tailings dams. In Geotechnical Practice in Dam Rehabilitation, ASCE, 402-415

Vick, S.G. (1983). Planning, design and analysis of tailings dams. John Wiley \& Sons

Villavicencio, G. Espinace, R. Palma, J. Fourie, A. and Valenzuela, P. (2014). Failure of sand tailings dams in a highly seismic country. Canadian Geotechnical Journal 51(4), 449-464

Wei, Z., Yin, G., Wang, J.G., Wan, L. and Li, G. (2013). Design, construction and management of tailings storage facilities for surface disposal in China: case studies of failures. Waste Management \& Research 31(11), 106-112

Xin, H., Finn, W. and Wang, Y. (1992). Lessons from seismic performances of Chinese tailings dams. Report of Department of Civil Engineering, University of British Columbia, Canada 